\title{
The University as an Educational Institution With Values in the Knowledge Society
}

\author{
María-José Gómez-Aguilella \\ Correspondence: María-José Gómez-Aguilella, PhD, Valencian International University (VIU), C/ Pintor Sorolla 21, \\ Valencia 46002, Spain.
}

Received: February 24, 2020 Accepted: April 2, 2020 Online Published: April 9, 2020

doi:10.5539/res.v12n2p20

URL: https://doi.org/10.5539/res.v12n2p20

\begin{abstract}
In this paper, we present a study which analyzes the relation between educational institution with the values of their students, all related with the knowledge society. The specific profile, young university students, help us to determine their prospects in the actual framework and beyond. The research is also focused on a specific country, Spain, although cross-cultural studies are being developed. The surveys were recruited through an online survey, the best way for our target to participate. We conduct a survey in which we elicited the importance of university like an educational institution regarding the knowledge society frame, as well as the values of their students depending on the election of the educational institution. This allows us to determine if the election of the educational institution is related with the values of their students, and if these values determine the election of the university. We try to establish by means of a quantitative study the profile of these students. For this reason, the study reveals knowledge of a new relations in specific variables, determined by the experience lived, which is an area of research that has received little attention to date. The variables to investigate are Knowledge society, educational institution and values (of their students) and its relation.
\end{abstract}

Keywords: educational institution, university, values, students, knowledge society

\section{Introduction}

The university has become the subject of much critical debate in the social sciences in recent years. The dominant opinion says that they are organized networks of socialization experiences that prepare people to act in society (Meyer, 1977). The forms of knowledge that the university has prized are being challenged by new forms of knowledge valued in the wider world (Barnett, 2000). It is clear that the path that has led us to place ourselves in the current society of knowledge and the consequent democratic requirement, as well as universalized higher education are substantially modified (De Espinosa, 2001). By combining interests, positions and group strength, they demanded recognition as a social and cultural institution, so they achieved a place in the history of European peoples (Pichardo and Oliva, 2013).

Initially the university was conceived as a commitment to advance knowledge, by professors and students. Instead, those foundational principles are being lost through a long and complicated process (Giménez-Amaya and Sánchez-Migallón, 2011). The task of the university, science, as well as research, teaching and education, all linked to communication, is carried out within the framework of an institution (Jaspers, 2013), you should not lose sight of the educational task, despite the sociological changes. "The interest is directed, then, to the spheres of knowledge in which the exact, demonstrable truth is possible" (Guardini, 2012: 75). The university exists to design and assemble the cultural and human features of an expanded map of a niversalistic cosmos. Education within the university must perform in a distinctive way, so as to provide society with knowledge valued by itself (Giménez-Amaya and Sánchez-Migallón, 2011).

In this study, we investigate values in educational institution, testing hypotheses concerning the effects of knowledge society, and direct and indirect effects of values of the students. There are some specific words that we need to explain in advance, like university or educational institution. In the literature the major part of authors investigate with the name of "university", in spite of this, for the methodological part we prefer the term "educational institution" because in this case includes universities, business schools and other kind of school organization. Then is more democrative for the students and researchers. Other specific part, the use of the term "values" in a general way and not with specifical possible values. This is because in this occasion we are not going to investigate within other specific variables, this point it would be for a future research.

Consequently, the variables to investigate are Knowledge society, educational institution and values (of their students) and its relation. These hypotheses are tested among university students, who are more individualistic compared to the 
rest of the society (Karakitapoglu-Aygun \& Imamoglu, 2002). The theoretical background of the study and the methodology are outlined in the next sections. We then present our findings in a methodolical part and conclude with a discussion of implications for future research.

\section{Educational Institution in the Knowledge Society}

The university can not enlighten society as lighting model took college, but can provide structures for public debate between experts and lay cultures (Delanty, 2001). The number of universities globally has extended exponentially, and nearly all nation-states now have universities (Riddle 1989, 1993; UNESCO 2005).

Moreover, the quantitative and experimental methods associated with such an approach often fail to provide adequate insights into the social and contextual complexity of the educational process (Hammersley, 1997; Scott \& Usher, 1999). The role of structure is vital with respect to identifying the knowledge generation developments (Zougris, 2018). The ethical concept revolves around the responsibility that the university as an institution that is an important part of in a community and within society can and should train people in solidarity with that context (Domínguez-Pachón, 2010). With this, it could be said that the two main intentions of the University are, essentially, the human and professional training that would respond to the academic field, as well as the construction of new knowledge as a direct objective of the research (Domínguez-Pachón, 2010). Conceptualizing the modality of activity is a very inspiring task (Zougris, 2018).

According to some authors, the university is distant from inappropriate to capitalism, as the preceding thesis would entitlement, but is in fact completely combined into it and, as a new manageralism takes over the university, there is a consequential loss of academic autonomy (Curie and Newson, 1998; Etzkowitz and Leydesdorff, 1997; Slaughter and Leslie, 1997). This thesis suggests that the university has become a major player in the global market and in information-based capitalism (Delanty, 2001).

It treats as peripheral the fact that modern educational systems are society-wide and state-controlled institutions (Wheeler 1966). But the essential fact is that within these new paradigms there are still solid foundations for their role with society. For this Domínguez-Pachón comments that in order for the university's stamp to be in a responsible way, it must intercede through different actions that are of a significant nature and, in turn, universities must be transparent to also be influenced by said society that it involves them, without structural blockages and, essentially, with a motivation that makes them participate in the improvement of vulnerable groups. (Domínguez-Pachón, 2010).

We face the objection of the undeniable projection of valuations and conceptions of life in ethical discourse, where the conviction that pushes us to justify our valuations and ethical attitudes implies content of an ethical nature (Sánchez-Migallón, 2008). Ethics, understood by authors as a critical reflection on values, provides us with reasons that justify actions or not, so that moral behaviors are analyzed. Ethics explains, from its universality, the human moral experience and establishes the modes of behavior in a justifiable way (Bolívar, 2005). Therefore, having ethics in the different spheres of social life (Cortina, 2011). Consequently, students are aspired to be integral and practice honesty, responsibility, kindness, modesty, duty, respect, solidarity, truth, belonging, honesty, tolerance, strength, prudence and fidelity, among many other values. Without giving priority levels, it is therefore considered that, depending on the circumstances in which they are, they correspond to a person of integral values (Hodelín-Tablada and Fuentes-Pelier, 2014).

The identity of the university is determined neither by technocraticmanagerial strategies nor by purely academic pursuits: in the 'knowledge society' knowledge cannot be reduced to its 'uses' or to itself because it is fixed in the deeper cognitive developments of society, in theoretical structures and in the epistemic structures of power and interests (Delanty, 2001).

\section{The Importance of Values in an Educational Institution}

Moral values are found to play an important role, but other values also influence the ethical decisions (Greenbank, 2003). Although research appears to support philosophical morals that denounce materialism as an individual and social peril, the debate over materialism is not yet conclusive (Karabati \& Cemalcilar, 2010). New and broad images of the world, individualized people and humanity, all conceived on universalist bases, strengthened considerably (Boli 2005). To know the mission of the university, it is worth mentioning that it is the institution where higher education is received, not the only type, but where the highest academic badges are received and where the most qualified professors and researchers must be. People are easily habituated with the material conditions (Csikszentmihalyi, 1999) and the collective effect of the adjustment with such avoidance is often unfavorable for welfare (Karabati and Cemalcilar, 2010). The value can be expressed in the action in a rigid or flexible way (González-Maura, 2000). Values are predominantly critical for institutional rhetorics (Mohr and White, 2008). This flexibility is discovered when the value is what regulates the performance of the subject not in a mechanical and absolute way, but from a situation analysis of a specific nature that is presented, with this also the search for possible alternatives to the problems that the subject faces in his performance 
(Leontiev, 1981). In this way, flexibility represents a higher level of value performance in the regulation of its action (González-Maura, 2000). This value from the motivational point of personality has several strata to function in the regulation of acting. These values can regulate the particular performance in a persevering or inconstant way, and also they have an individual cut as well as supra-individual, being part of a social reality, this fact makes the actuality of that context interfere with what happened within the social life and the needs of this society, in addition to historically affecting the system of values officially instituted in a specific society (González-Maura, 2000).

Another aspect that stands out within this mission of the university is the search for vocations to contemplate quality education, precisely the lack of professionals and researchers was what delayed the correct development of the university in Spain. Therefore, university education thus focused on two objectives: professionalization and research (Hernández and Jara, 2002). Values are organized in relational systems that deliver anchors for the explanatory considerations (Mohr and White, 2008).

Kohn's research (1969, and subsequently) shows exactly the same result (Meyer, 1977). Since they had been based on observing and imitating what was being done in other universities without raising the question of whether it was actually developing in an adequate way or not, the reality was that they were homogenizing on a way. "The university is an institution that governs itself, an institution of public law" (Jaspers, 2013: 197). But the Catholic university is the one that can offer a greater degree of wisdom for its interest in knowledge, with an openness to unlimited dialogue, returning to truth and good (Giménez-Amaya and Sánchez-Migallón, 2011). The quality of higher education is not only resolved with the achievement of a product consistent with its quality processes as efficiency, but also for the achievement of a product consistent with its goals and objectives, where there must also be coherence of the goals sought with values, expectations and social needs (De la Orden et al., 1997). At a time like the current one, in which university systems are undergoing profound changes (Casares-García et al., 2010). Due to the fact that ethical value perfects man in terms of being a man, in his will, in his reason and prepares him to live in a collective (Hodelín-Tablada and Fuentes-Pelier, 2014). As a consequence of the quality of hierarchy, values constitute codes where they are ordered hierarchically to fulfill the role of making sense and guiding people, institutions, groups and societies. The value code does not have to be the same for each of these entities, although it is recognized that there is certain consensus that they can give them a more universal character (Barba-Martín and Alcántara-Santuario, 2003: 20).

Educational systems themselves are consequently, in a sense, ideas. They rationalize in modern terms and remove from sacred and primordial explanations the nature and organization of personnel and knowledge in modern society. In the education of values, a high mission has been assigned to the educational institutions, without a doubt, the universities constitute fundamental links in this process (Hodelín-Tablada and Fuentes-Pelier, 2014). It is the teacher's task to particularize in a conscious way so that students are effectively motivated in a way in which they are valued (Hodelín-Tablada and Fuentes-Pelier, 2014). Although the formation of the fundamental values of the human being occurs during childhood and in social life, we consider that it also concerns and especially importantly, formal education. (Barba-Martín and Alcántara-Santuario, 2003). Thus, it was possible to imagine the phenomenon of over-education, in which a surfeit of training signaled inefficiency in a nation-state's role-allocation system and possibly even led to social disorder and dreaded anomie (Frank \& Meyer, 2007).

\section{Hypotheses}

Education is a central component in the public profile of entities, which significantly affects their life opportunities. Such an organization clearly influences the social order beyond the immediate socialization practices it offers to young people (Meyer, 1977).

Virtually all elite occupations globally are certified by the university (Sullivan 2005), and nearly all the world's stratification systems are legitimated by university-based knowledge (Frank \& Meyer, 2007). The "knowledge society" that results is distinguished by the extraordinary degree to which the university is linked to society (Frank \& Meyer, 2007). Therefore, it is argued that:

\section{H1: Knowledge society has a direct influence on educational institution}

The university is, then, more than an institution of knowledge production but has also nurtured the dominant and emergent cultural models of society (Delanty, 2001). When people's basis needs are more or less fulfilled, it should be expected that incremental income will go to products that fit their values (de Mooij, 2010). The university's students and academic contents increasingly took on national meanings and purposes (Altbach 1998). Therefore, it is proposed that:

\section{H2: Educational institution has a direct influence on values of their students}

For the university's knowledge and knowers, and for the pedagogy that connects them, the implications of society's reinvention are striking (Frank \& Meyer, 2007). If education is a myth in modern society it is a powerful one (Meyer, 
1977). Simultaneously, the liberal victory animated the move toward a new world society, collected of individualized persons, commonly considered as autonomous, equivalent actors with a extensive range of civil rights (Suárez 2007; Tsutsui and Wotipka 2004). The university can be reborn (Barnett, 2000). Based on these findings, it is argued that:

\section{H3: Values of their students has a direct influence on educational institution}

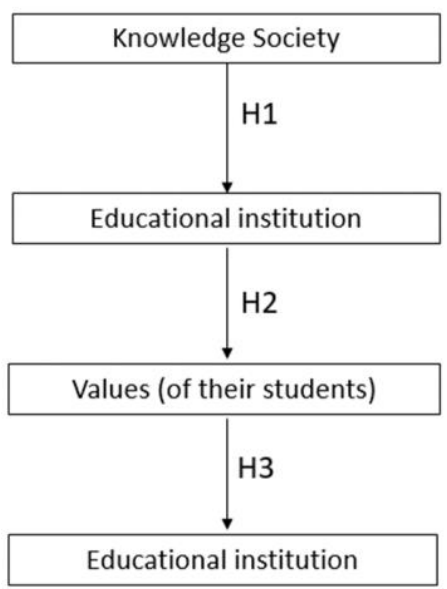

Figure I. Model

\section{Research Method}

From this model (figure I) with three variables it was made a survey with 7 sentences related with the variables. The way to know the grade was with a 5 Likert scale (Table 1). The survey asked the degree of agreement of the 7 sentences, where 1 was little agreed and 5 was very agree.

A convenience sample of 120 university students in Spain was recruited through an online survey. The survey was announced initially on e-groups for university students in communication and advertising, groups well-known for their activities. The announcement included a synopsis of the goals of the study, contact information of the researcher, and the hyperlink to the questionnaire made available on an online survey site. The author also sent the survey announcement directly to students in their own classes. Participation was on a voluntary basis and anonymity was maintained.

Table I. Variables and items

\begin{tabular}{ll}
\hline \multicolumn{1}{c}{ Sentence } & \multicolumn{1}{c}{ Variables } \\
\hline $\begin{array}{l}\text { 1. The university is an important educational institution in } \\
\text { our society }\end{array}$ & $\begin{array}{l}\text { Educational institution/ } \\
\text { Knowledge society }\end{array}$ \\
$\begin{array}{l}\text { 2. The university has always been an important educational } \\
\text { place }\end{array}$ & $\begin{array}{l}\text { Educational institution/ } \\
\text { Knowledge society }\end{array}$ \\
$\begin{array}{l}\text { 3. Knowledge society is the basis of the educational } \\
\text { institution }\end{array}$ & $\begin{array}{l}\text { Knowledge society/ } \\
\text { Educational institution }\end{array}$ \\
\hline $\begin{array}{l}\text { 4. The educational institution is an important point in our } \\
\text { knowledge society }\end{array}$ & $\begin{array}{l}\text { Educational institution/ } \\
\text { Knowledge society }\end{array}$ \\
\hline $\begin{array}{l}\text { 5. Your election of educational institution demonstrates your } \\
\text { type of values }\end{array}$ & $\begin{array}{l}\text { Educational institution/ } \\
\text { Values (of their } \\
\text { students) }\end{array}$ \\
\hline $\begin{array}{l}\text { 7. Your values are related with your election of educational } \\
\text { institution }\end{array}$ & $\begin{array}{l}\text { Values (of their } \\
\text { students)/ Educational } \\
\text { institution }\end{array}$ \\
\hline $\begin{array}{l}\text { values } \\
\text { Values (of their } \\
\text { students)/ Educational } \\
\text { institution }\end{array}$ \\
\hline
\end{tabular}




\section{Results and Analysis}

The analysis of the data obtained in the questionnaires demonstrates the hypothesis and the relationships between variables. A total of 87 responses were usable for analyses (Table 2). From the measurement of the variables (Knowledge society, educational institution and values) and the number of items used for each scale, as well as the references used, the instrument was validated by first contrasting the model with a confirmatory factor analysis structural equation.

Our results are shown in Table 3. It has been demonstrated that there is a strong relationship between the variables with a high punctuation between them. Sentences related to Knowledge society and Educational institution are the highest numbers. The paper of the university in the society is demonstrated, and the also the relations among the variables.

Table II. Sample Characteristics

\begin{tabular}{ll}
\hline Demographic variables & Desciption and percentage \\
\hline Age & 19 years old: $74,8 \%$ \\
& 20 years old: $19,5 \%$ \\
& 21 years old: $5,7 \%$ \\
\hline Gender & Female: $87,3 \%$ \\
& Male: $12,6 \%$
\end{tabular}

Table III. Sentences and average

\begin{tabular}{lc}
\hline \multicolumn{1}{c}{ Sentence } & $\begin{array}{c}\text { Average rating scale } \\
\text { Likert }\end{array}$ \\
\hline $\begin{array}{l}\text { 1. The university is an important educational institution in } \\
\text { our society }\end{array}$ & 4.1 \\
$\begin{array}{l}\text { 2. The university has always been an important educational } \\
\text { place }\end{array}$ & 4.8
\end{tabular}

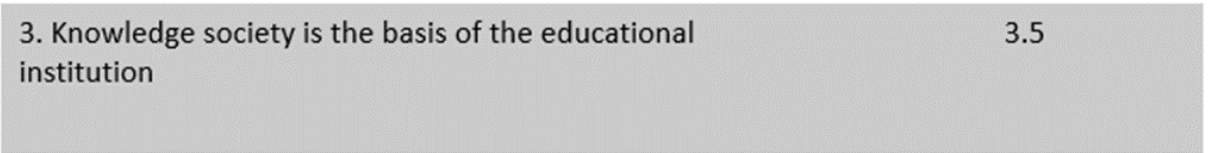

4. The educational institution is an important point in our knowledge society

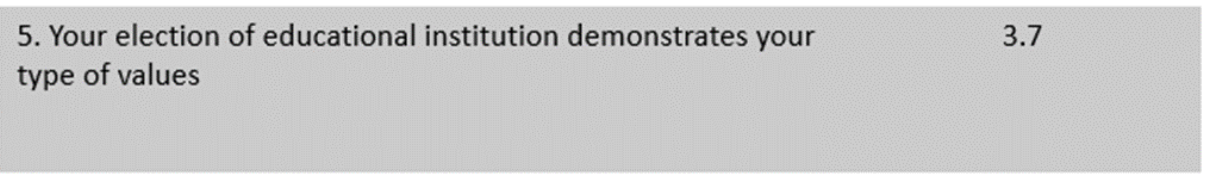

6. The educational institution is essential for your kind of values

7. Your values are related with your election of educational institution
3.1

4.4 
While the qualities of data available for analysis were quite small, the findings of hypotheses result in positive feedback (Table 4).

Table IV. Relationships in model

\begin{tabular}{ccc}
\hline H & Relation & Results \\
\hline H1: & Knowledge society $\rightarrow$ Educational institution & accepted \\
\hline H2: & Educational institution $\rightarrow$ Values (of their students) & accepted \\
\hline H3: & Values (of their students) $\rightarrow$ Educational institution & accepted \\
\hline
\end{tabular}

\section{Conclusions and Limitations}

While the results of this study cannot be generalized due to the limited geographical coverage both with respect to origin and institution and due to the response rate, this exploratory study does suggest that the educational institution affects in the values of their students and also on the contrary way. All of this with the framework of the knowledge society. The great paper of the educational institution on the society, since the beginning of this institution until now is proven with our results. For this people, young students, the educational institution has always been essential.

The new university knowledge, as means for collective ends, promised benefits (Frank \& Meyer, 2007). Universities, after all, have a strong self-sense of themselves in terms of the knowledge enterprise, as we might term it (Barnett, 2000). Then, that knowledge has given way to knowledges (Barnett, 2000). The university survives and flourishes, as a grand and cohesive scheme, precisely because what are forged at its core are not mundane skills but rather the transcendent principles that constitute the knowledge society's foundations (Frank \& Meyer, 2007).

Finally, a possible limitation of this research is that it focused mainly on data collected from Spanish students and is not representative of the total students. Another possible limitation lies in the fact that the research based on the selected literature focused only on three variables. Further study could discriminate among nationalities and gender, as students or Universities for different nationalities and sexes may differ.

\section{References}

Altbach, P. G. (1998). Comparative higher education: Knowledge, the university, and development. Greenwood Publishing Group.

Barba, M. L., \& Alcántara, S. A. (2003). Values and university education. Reunion, (38), 16-23.

Barnett, R. (2000). University knowledge in an age of supercomplexity. Higher education, 40(4), 409-422.

Bloom, A. (1987). The Closing of the American Mind. New York: Simon \& Schuster.

Boli, J. (2005). Contemporary developments in world culture. International Journal of Comparative Sociology, 46(5-6), 383-404.

Bolívar, A. (2005). The place of professional ethics in university education. Mexican magazine of educational research, 10(24), 93-123.

Bourdieu, P. (1988). Homo Academicus. Cambridge: Polity Press.

Bourdieu, P. (1996). The State Nobility. Cambridge: Polity Press.

Casares, G. P. M., Carmona, O. G., \& Martínez-Rodríguez, F. M. (2010). Professional values in university education. Electronic magazine of educational research, 12(SPE), 1-15.

Clark, B. (1970). The College as Saga: Historical Inquiry in the Sociology of Education. In annual meeting of the American Sociological Association, Washington, DC, August. Mimeographed. New Haven, Conn.: Department of Sociology, Yale University.

Cortina, A. (2011). Deliberative democracy. Contrasts. International Journal of Philosophy.

Csikszentmihalyi, M. (1999). If we are so rich, why aren't we happy? American psychologist, 54(10), 821. 
Curie, J., \& Newson, J. (Eds.). (1998). Universities and Globalization: Critical Perspectives. London: Sage.

De Espinosa, E. L. (2001). The reform of the university in the knowledge society. Reis, (93), 243-255.

De la Orden, A., Asensio, I., Carballo, R., Fernández, D. J., Fuentes, A., García Ramos, J. M. et al. (1997). Development and validation of a university quality model as the basis for its evaluation. Electronic Journal of Educational Evaluation, 3(1).

De Mooij, M. (2010). Consumer behavior and culture: Consequences for global marketing and advertising. Sage.

Delanty, G. (2001). The university in the knowledge society. Organization, 8(2), 149-153.

Domínguez-Pachón, M. J. (2010). University social responsibility. Humanism and Social Work, 8(37-67).

Etzkowitz, H., \& Leydesdorff, L. (Eds.) (1997) Universities in the Global Economy: A Triple Helix of University Industry Government Relations. London: Cassell Academic.

Frank, D. J., \& Meyer, J. W. (2007). University expansion and the knowledge society. Theory and society, 36(4), 287-311.

Gibbons, M. et al. (1994). The New Production of Knowledge. London: Sage.

Giménez-Amaya, J. M., \& Sanchez, M. S. (2011). Diagnosis of the University in Alasdair MacIntyre. Genesis and development of an anthropological project, EUNSA, Pamplona 2011.

Goldberg, M. E., Gorn, G. J., Peracchio, L. A., \& Bamossy, G. (2003). Understanding materialism among youth. Journal of Consumer Psychology, 13(3), 278-288.

González-Maura, V. (2000). The education of values in the university curriculum: A psychopedagogical approach to its study. Higher Medical Education, 14(1), 74-82.

Greenbank, P. (2003). The role of values in educational research: The case for reflexivity. British educational research journal, 29(6), 791-801.

Guardini, R. (2012). Three writings about the University. Eunsa

Hammersley, M. (1997). Educational research and teaching: a response to David Hargreaves' TTA lecture. British Educational Research Journal, 23(2), 141-161.

Hernández, A. G., \& Jara, F. V. (2002). Concept and mission of the university. From Ortega y Gasset to the university reform of nationalism-Catholicism. Spanish magazine of comparative education, (8), 137-174.

Hodelín Tablada, R., \& Fuentes Pelier, D. (2014). The university professor in the formation of ethical values. Higher medical education, 28(1), 115-126.

Jacoby, R. (1987). The Last Intellectuals: American Culture in the Age of Academe. New York: Basic Books.

Jaspers, K. (2013). The idea of the university. EUNSA.

Karabati, S., \& Cemalcilar, Z. (2010). Values, materialism, and well-being: A study with Turkish university students. Journal of Economic Psychology, 31(4), 624-633.

Karakitapoglu-Aygun, Z., \& Imamoglu, O. (2002). Value domains of Turkish adults and university students. The Journal of Social Psychology, 142(3), 333-351.

Keng, K. A., Jung, K., Jiuan, T. S., \& Wirtz, J. (2000). The influence of materialistic inclination on values, life satisfaction and aspirations: An empirical analysis. Social Indicators Research, 49(3), 317-333.

Kilbourne, W., \& Pickett, G. (2008). How materialism affects environmental beliefs, concern, and environmentally responsible behavior. Journal of Business Research, 61(9), 885-893.

Leontiev, A. N. (1981). Exercise. Awareness. Personality. Havana: Editorial People and Education.

Llano, A. (2003). Rethink the university: the university before the new. International University Editions.

Lyotard, J.-F. (1984). The Postmodern Condition: A Report on Knowledge. Manchester: Manchester University Press.

Malhotra, N. K., Wu, L., \& Allvine, F. C. (2006). Marketing reform: The case of excessive buying. In J. N. Sheth \& R. S. Sisodia (Eds.), Does marketing need reform? Fresh perspectives on the future (pp. 45-54). New York: M.E. Sharpe Inc.

Meyer, J. W. (1970). The charter: Conditions of diffuse socialization in schools.

Meyer, J. W. (1977). The effects of education as an institution. American journal of Sociology, 83(1), 55-77.

Meyer, J. W., Boli, J., Thomas, G. M., \& Ramirez, F. O. (1997). World society and the nation-state. American Journal of 
Sociology, 103, 144-181.

Mohr, J. W., \& White, H. C. (2008). How to model an institution. Theory Soc., 37, 485-512.

Parsons, T., \& Platt, G. (1973). The American University. Cambridge, MA: Harvard University Press.

Pichardo, P. J. M., \& Oliva, A. V. H. (2013). University social responsibility: a challenge of the Mexican public university. Contributions from Coatepec, (24), 85- 103.

Readings, B. (1996). The University in Ruins. Cambridge, MA: Harvard University Press.

Riddle, P. (1989). University and state: Political competition and the rise of universities, 1200-1985. Stanford University.

Riddle, P. (1993). Political authority and university formation in Europe, 1200-1800. Sociological Perspectives, 36, $45-62$.

Roets, A., Van Hiel, A., \& Cornelis, I. (2006). Does materialism predict racism? Materialism as a distinctive social attitude and a predictor of prejudice. European Journal of Personality, 20, 155-168.

Sánchez-Migallón, S. (2008). Philosophical ethics. Pamplona: Eunsa, 178.

Schofer, E., \& Meyer, J. W. (2005). The worldwide expansion of higher education in the 20th century. American Sociological Review, 70, 898-920.

Scott, D., \& Usher, R. (2010). Researching education: Data, methods and theory in educational enquiry. Bloomsbury Publishing.

Shils, E. (1973). Max Weber on Universities: The Power of the State and the Dignity of the Academic Calling in Imperial Germany. Chicago: University of Chicago Press.

Slaughter, S., \& Leslie, L. (1997) Academic Capitalism: Politics, Policies, and the Entrepreneurial University. Baltimore, MD: Johns Hopkins University Press.

Soares, J. A. (1999). The decline of privilege: The modernization of Oxford University. Stanford, CA: Stanford University.

Suárez, D. (2007). Education professionals and the construction of human rights education. Comparative Education Review, 51, 48-70.

Sullivan, W. M. (2005). Work and integrity: The crisis and promise of professionalism in America (2nd ed.). San Francisco: Jossey-Bass.

Tsutsui, K., \& Wotipka, C. M. (2004). Global civil society and the international human rights movement: Citizen participation in human rights international nongovernmental organizations. Social Forces, 83(2), 587-620.

UNESCO. (2005). Statistical yearbook. Paris: UNESCO.

Wheeler, S. (1966). The structure of formally organized socialization settings. Socialization after childhood, 53-116.

Zougris, K. (2018). Communities of scholars: A conceptual scheme of knowledge production. Societies, 8(4), 118.

\section{Copyrights}

Copyright for this article is retained by the author(s), with first publication rights granted to the journal.

This is an open-access article distributed under the terms and conditions of the Creative Commons Attribution license (http://creativecommons.org/licenses/by/4.0/). 